\title{
Rehabilitation of a Female Patient after Corrective Surgery for Tetralogy of Fallot
}

\author{
Jovana Cvetković1, Dragan Đorđević1,2, Milan Šljivić1, Marina Deljanin Ilić1,2 \\ ${ }^{1}$ Institute for Treatment and Rehabilitation "Niška Banja", Niška Banja, Serbia \\ 'University of Niš, Faculty of Medicine, Niš, Serbia
}

\begin{abstract}
SUMMARY
Herein we present a 25-year-old female patient with tetralogy of Fallot (TOF). This congenital heart defect is not very common, but it is the most common one among cyanotic heart defects. Treatment of the patients with TF is surgical, with palliative or curative (corrective) intent. Our patient underwent palliative surgery, definitive correction, and another surgery for pulmonary valve insufficiency. During cardiovascular rehabilitation, the patient was rhythmically stable, with excellent tolerance of physical exertion. Bearing in mind that this was a young female person who previously had had two spontaneous abortions, pregnancy was not absolutely contraindicated, although spontaneous abortion and pregnancy complications were more common in these patients.
\end{abstract}

Key words: tetralogy of Fallot, corrective surgery, pulmonary regurgitation, pregnancy 


\section{INTRODUCTION}

The incidence of tetralogy of Fallot (TOF) is $0.5 / 1000$ live births (accounting for 5-7\% of all congenital heart diseases). In the past, when surgical correction of TOF was not an available treatment option, around $50 \%$ of patients with this heart defect died within their first year of life and it was unusual that these patients live longer than 30 years (1). Nowadays, corrective surgical treatment is very effective and enables operated patients to lead a normal life (2). Pathological characteristics of this cyanotic heart disease were first described in 1888 by a French physician, Louis Arthur Fallot. Classically, there were four major abnormalities associated with the defect: 1) infundibular pulmonary stenosis; 2) dextraposition of the aorta; 3) ventricular septal defect (VSD) and 4) right ventricular hypertrophy. Etiologically, the defect can be the result of genetic factors (mutation of the alpha myosin heavy chain, trisomy $13,18,21$, microdeletion of $1,21,8$ (3) or it is caused by conditional influences from the environment during the first trimester of pregnancy (extreme obesity, various teratogenic factors in the first trimester of pregnancy, viral infections, $x-$ rays, drugs, avitaminosis, alcohol intake, stress).

\section{CASE REPORT}

I.A., a female patient from Majdanpek, 25 years old, was born with TOF. In 1991, she underwent Blalock-Taussig bypass palliative surgery. This shunt functioned for 6 months, and afterwards the signs and symptoms of anoxic crisis appeared. In 1999, the patient underwent definitive correction of the defects: VSD closure with a Gore-Tex patch, suture of the foramen ovale apertum, resection of the right ventricular outflow tract and reconstruction of the main stem and both branches of the pulmonary artery with a pericardial patch. In the following years the patient had no symptoms, was physically active, and engaged in sports. In 2012, at a regular echocardiographic follow-up examination, a severe pulmonary regurgitation was detected. The patient was asymptomatic all the time. Echocardiography showed the following: in the place of suture VSD without left-right shunt; right heart chambers slightly enlarged: right ventricle $47 \mathrm{~mm}$ (four-chamber view), outflow tract $37 \mathrm{~mm}$, pulmonary artery $37 \mathrm{~mm}$, the branches - left $11 \mathrm{~mm}$, right $13 \mathrm{~mm}$; pulmonary valve was not visible; pulmonary regurgitation 3-4+; tricuspid regurgitation $1-2+$ and systolic pressure in the right ventricle $30 \mathrm{~mm}$.

24-hour Holter ECG revealed the episodes of supraventricular tachycardia and because of that the patient was treated with propafenone for some time. Replacement of the pulmonary valve with artificial prosthesis was indicated. Pulmonary valve replacement with biological prosthesis (Hancock II porcine heart valve No. 25) was performed on July 8 , 2014. The operation and early postoperative period passed without complications. The patient also reported two spontaneous abortions in the preceding two years. Her family history showed that her father had suffered from hypertension.

On admission to our Institute for Rehabilitation the patient was feeling well. The status was without any special observations, except for the heart auscultation findings: accented and split second sound was registered, systolic ejection-type murmur above the pulmonary artery (grade III); blood pressure 100/70 $\mathrm{mmHg}$; on admission, the heart rate was $88 / \mathrm{min}$. The ECG tracing showed a complete block of the right bundle branch, first-degree atrioventricular block (280 ms), without ventricular or atrial heart rhythm disturbances (Figure 1). 


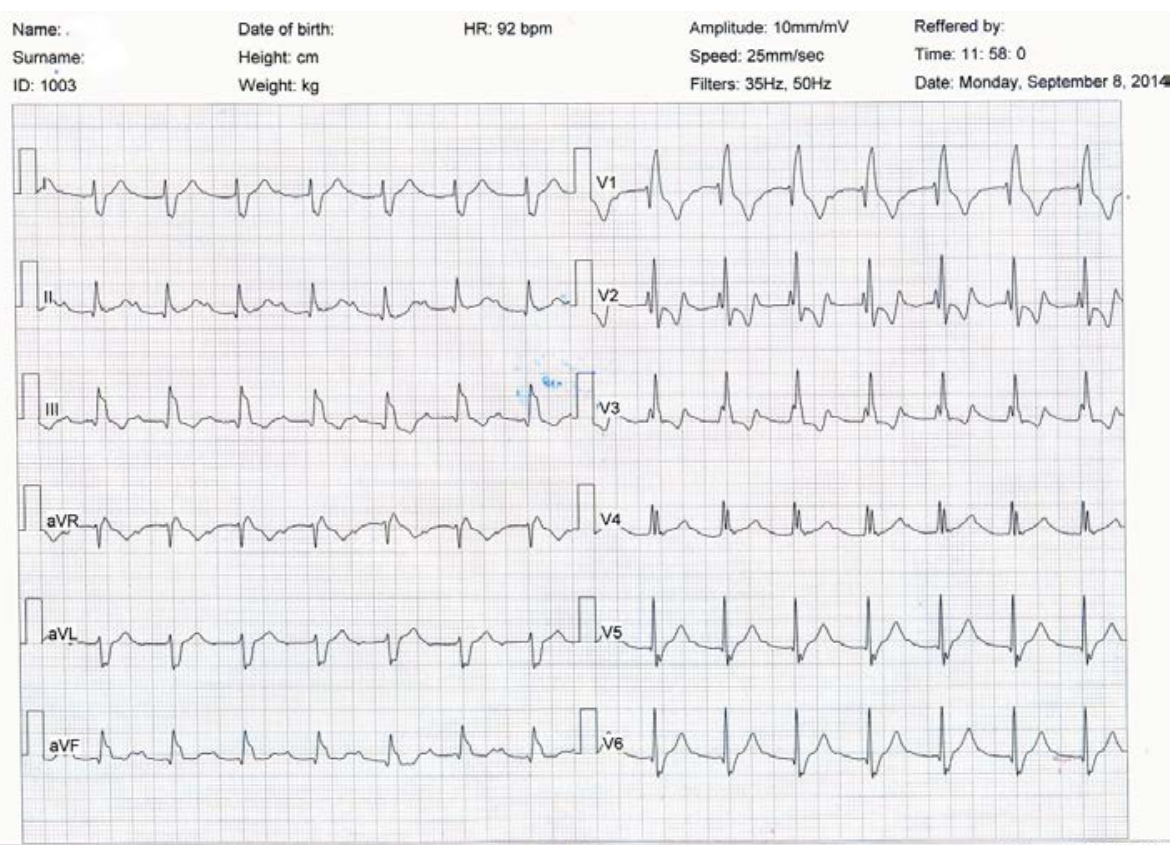

\section{Figure 1. Electrocardiogram: right bundle branch block and atrioventricular block of first degree}

The echocardiography study during rehabilitation showed the following: the left ventricle was normal in size (44 mm end-diastolic diameter) and shape, with preserved global systolic function (ejection fraction $66 \%$ $\mathrm{M}$ mode) and normal wall thickness (Figure 2). There was no communication between the chambers. The left ventricle and aorta were of normal width. Right ventricle (22 $\mathrm{mm}$ from parasternal long axis view) and atrial diameters were normal. The artificial pulmonary valve was of gradient of $18 / 12 \mathrm{mmHg}$ and without regurgitation (Figure 3). Tricuspid regurgitation was 1+, jet velocity was $2.45 \mathrm{~m} / \mathrm{sec}$, and the pressure in the right ventricle during systole was $34 \mathrm{mmHg}$. The pericardium was characterized by increased echogenicity, without effusion.

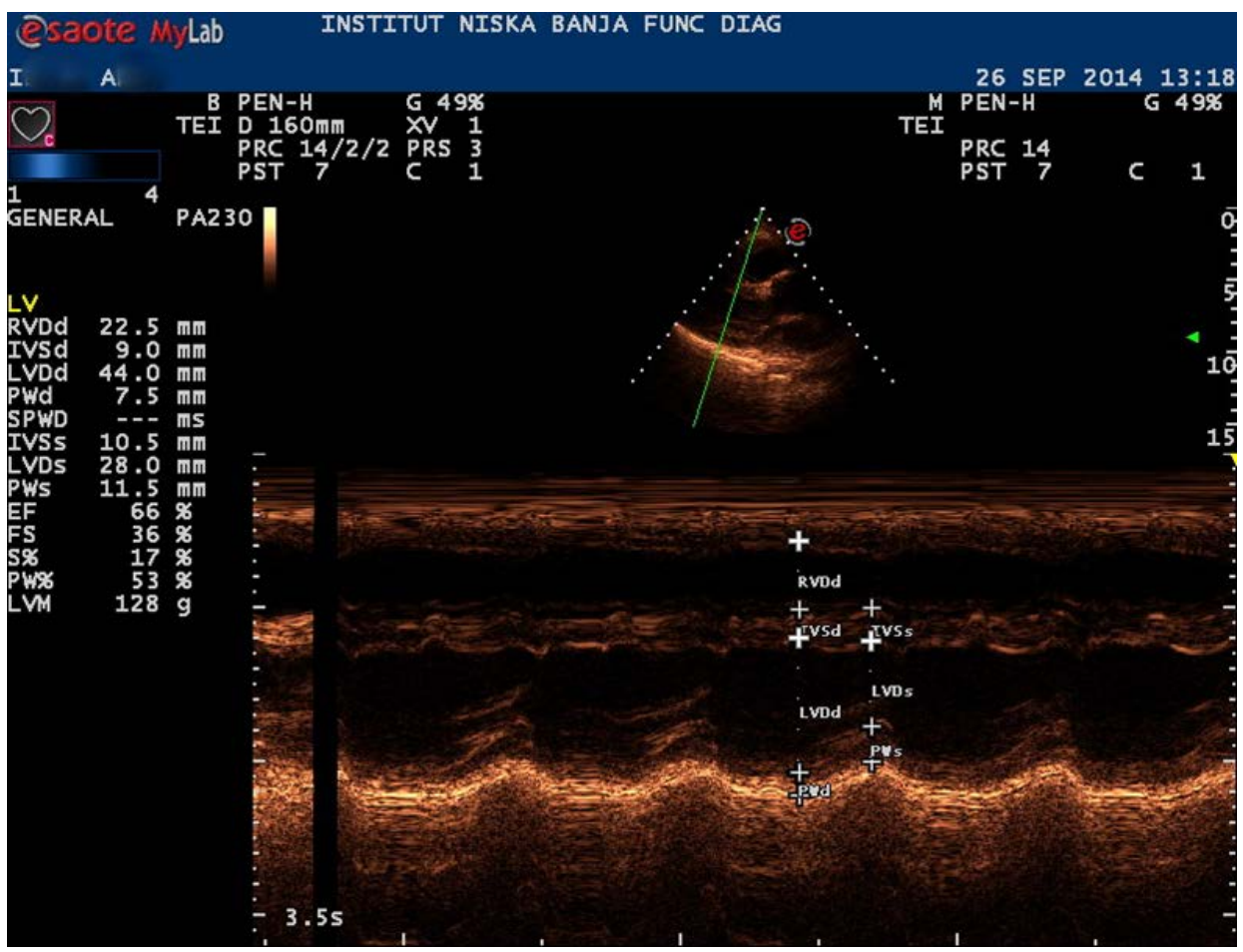

Figure 2. M mode echocardiogram - parasternal long-axis view 


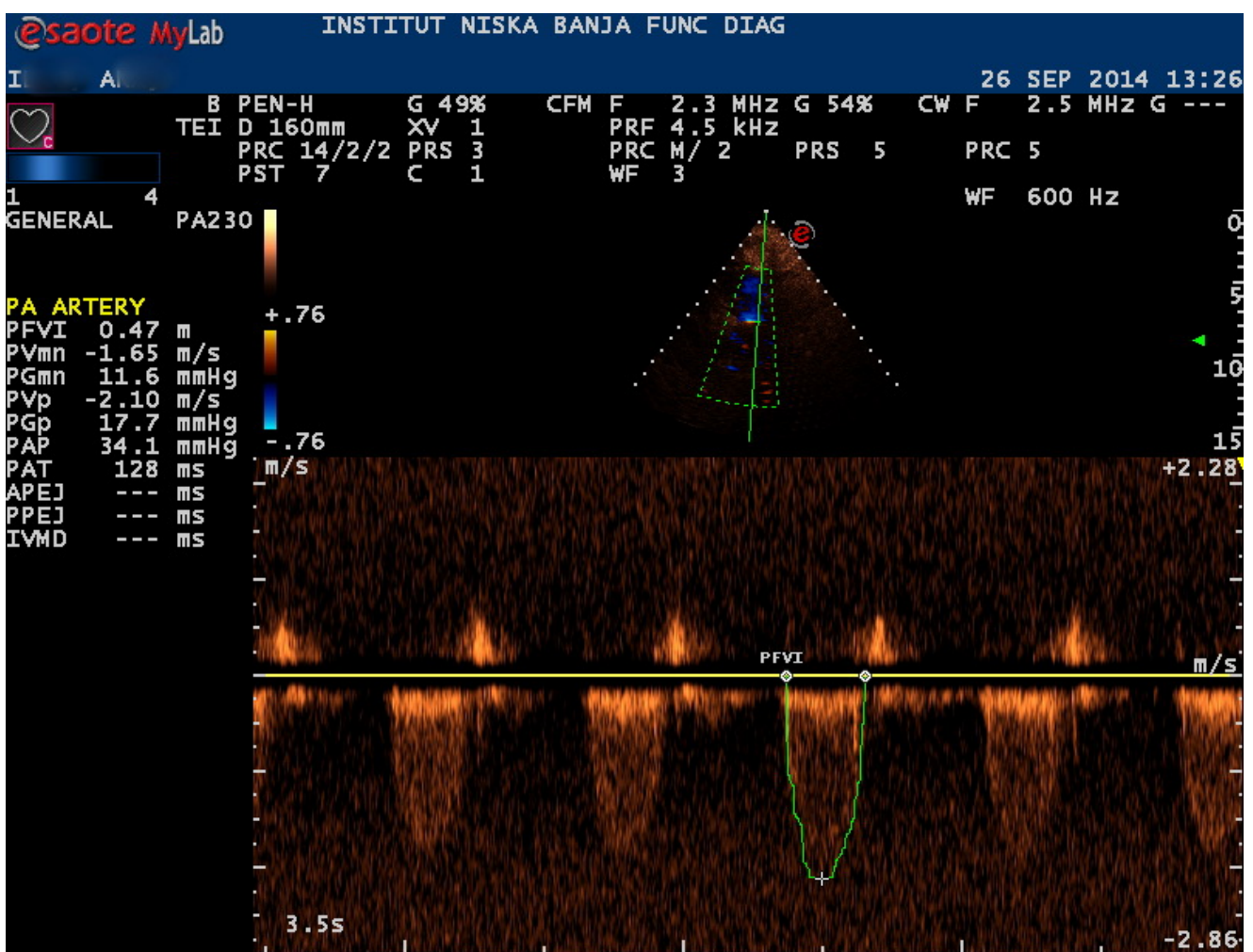

Figure 3. Flow through the artificial pulmonary valve, shown by continuous Doppler from parasternal short axis view of pulmonary artery

During the patient's stay at the Institute, a program of specialized rehabilitation was conducted gradually increasing her physical activity (progressive increasing load on the walkways; maximum cycle ergometer training at $75 \mathrm{~W}, 2 \times 3$ minutes duration; gymnastics for patients with cardiovascular diseases with the aim of increasing of the exercise tolerance and muscle strength; hydrotherapy in the pool), which passed without any symptoms. On daily reviews (21-day rehabilitation), rhythm disorders or hemodynamic instability were not observed. On discharge from the residential rehabilitation center, the patient was instructed to continue with antiplatelet therapy (acetylsalicylic acid $100 \mathrm{mg}$ per day).

\section{DISCUSSION}

The treatment of patients with TF is surgical and can be palliative and correcting. Nowadays, the Blalock-Taussig shunting is performed only in those who cannot undergo or, due to anoxic episodes, cannot wait for final surgical resolution of the defect. Generally, it is recommended that all patients should be surgically treated till the end of their first year of life. At present, it is thought that early corrective surgical intervention provides the survival with a smaller number of reoperations later in life. The main complication that occurs later in life in patients who underwent either palliative or corrective surgery at a young age is related to progressive dilatation of the right ventricle because of long-term pulmonary regurgitation caused by the correction of the narrow right ventricular outflow tract. The most important complication that occurs due to these changes is sudden cardiac death caused by ventricular arrhythmias (4-6). The survival of patients after corrective surgery of TOF is prolonged, but is still shorter than the survival of people without the disease. Studies have shown that in those patients in whom the corrective surgery was done earlier, who had not polycythemia, and whose right ventricle was not significantly increased before surgery and in whom there was no need to patch the pulmonary artery, there was no statistically significant difference in overall survival compared to people without the defect (5). The leading cause of mortality of patients after surgical correction of TOF is sudden cardiac death caused by ventricular arrhythmias of persistent ventricular tachycardia type $(4,7)$. The risk factors for ventricular arrhythmias are older age at the time of surgery, increased pressure in the right ventricle, 
pulmonary regurgitation of medium or severe degree, left ventricular dysfunction, and longer duration of cardiopulmonary bypass $(8,9)$. A late complication in patients after surgical correction of TOF is pulmonary regurgitation, which is the leading cause of dilatation of the right ventricle, stress intolerance, arrhythmias and sudden cardiac death $(10,11)$.

The rehabilitation of patients with valvular defects (corrected and uncorrected) involves physical training, correction of cardiovascular risks, correction of drug treatment, education of patients about their disease and improvement of their psychological status. Any such rehabilitation attempt is conducted in three phases. In our Institute, the third rehabilitation phase is implemented, i.e. a prolonged rehabilitation (12). Since congenital heart defects are detected and surgical management occurs mostly in younger individuals, it is essential that these patients return to their regular physical activity as soon as possible after the operation. Physical training is thus of utmost importance in any such rehabilitation program. Each physical activity can be categorized as static or dynamic, and as to intensity, it can be described as low, moderate or vigorous activity. Any decision to involve patients in a physical training program should be individualized. Intense physical activity should be encouraged only in patients with minimal residual abnormalities (13). In our Institute, cycle ergometer training is organized, which permits precise workload calculations and control of heart frequency and blood pressure, as well as walk training at a pre-defined pace along the established walkways. The patient reported here had a precisely dosed physical training with a progressively increasing workload and hydrotherapy in a pool. Close surveillance of patients during their physical training is essential (14). Earlier studies have shown that after a six-month physical training in patients after heart valve surgery their quality of life was significantly improved (15). A study was conducted to examine the effect of a twelve-week aerobic dynamic physical exercise on heart muscle remodeling in patients after corrective TOF surgery, which demonstrated that there were no harmful effects of physical training on cardiac remodeling (14). According to the results of this study, repeated physical training reduces long-term risk for coronary disease, improves physical fitness and quality of life (16). In our patient, there were no limitations in the implementation of rehabilitation program, since there was no heart failure nor life-threatening arrhythmia: a full-scale physical training program was done and was well tolerated by the patient.

It has been proven that the percentage of spontaneous abortions is higher in women with TOF and those with surgically treated TOF than in women who do not have this heart defect. Pulmonary regurgitation is associated with poor outcome in early pregnancy, especially when accompanied by right ventricular dysfunction (17). Our patient had two spontaneous abortions, although the right ventricular function was preserved. During pregnancy, women with TOF correction are at high risk for cardiovascular (cardiac arrhythmia, heart failure, heart attack, stroke, aortic dissection, thromboembolic complications) and obstetric complications (eclampsia, preeclampsia, premature birth and others). Abnormalities in the maternal hemodynamics as well as the use of cardiovascular drugs before and during pregnancy can lead to decreased blood flow through the placenta and compromised intrauterine fetal growth, possibly resulting in premature birth and low birth weight (18).

\section{CONCLUSION}

We presented a female patient who underwent the full-scale program of prolonged rehabilitation after a common disease course and surgical TOF correction. Bearing in mind that ventricular heart rhythm disorders were not registered, this was a case of preserved cardiac function, adequate biological pulmonary valve functions, and with good prognosis. Since this is a young woman, pregnancy is not contraindicated, although spontaneous abortions and pregnancy complications are more common in this patient subpopulation. 


\section{References}

1. Apitz C, Webb GD, Redington AN. Tetralogy of Fallot. Lancet 2009; 374: 1462-1471. http://dx.doi.org/10.1016/S0140-6736(09)60657-7

2. Reddy VM, Liddicoat JR, McElhinney DB, et al. Routine primary repair of tetralogy of Fallot in neonates and infants less than three months of age. Ann Thorac Surg 1995; 60: S592-6. http://dx.doi.org/10.1016/0003-4975(95)00732-6

3. Rauch R, Hofbeck M, Zweier, et al. Comprehensive genotypephenotype analysis in 230 patients with tetralogy of Fallot. J Med Genet 2010; 47:321-31.

http://dx.doi.org/10.1136/jmg.2009.070391

4. Murphy JG, Gersh BJ, Mair DD, et al. Long-term outcome in patients undergoing surgical repair of tetralogy of Fallot. NEJM 1993; 329:593-9. http://dx.doi.org/10.1056/NEJM199308263290901

5. Nollert G, Fischlein T, Bouterwek S, et al. Longterm survival in patients with repair of tetralogy of Fallot: 36-year follow-up of 490 survivors of the first year after surgical repair. JACC 1997; 30:1374-83.

http://dx.doi.org/10.1016/S0735-1097(97)00318-5

6. Gatzoulis MAM, Balaji SS, Webber SAS, et al. Risk factors for arrhythmia and sudden cardiac death late after repair of tetralogy of Fallot: a multicentre study. Lancet 2000; 356:975-81. http://dx.doi.org/10.1016/S0140-6736(00)02714-8

7. Gillette PC, Yeoman MD, Mullins CE, et al. Sudden death after repair of tetralogy of Fallot: electrocardiographic and electrophysiologic abnormalities. Circulation 1977; 56:566-71. http://dx.doi.org/10.1161/01.CIR.56.4.566

8. Chandar JS, Wolff GS, Garson A, et al. Ventricular arrhythmias in postoperative tetralogy of Fallot. Am J Cardiol 1990; 65:655- 61. http://dx.doi.org/10.1016/0002-9149(90)91047-A

9. Zahka KG, Horneffer PJ, Rowe SA, et al. Longterm valvular function after total repair of tetralogy of Fallot: relation to ventricular arrhythmias. Circulation 1988; 78 Suppl:III14 -9.

10. Webb Kavey R, Thomas FD, Byrum CJ, et al. Ventricular arrhythmias and biventricular dysfunction after repair of tetralogy of Fallot. JACC 1984; 4:126 -31.

http://dx.doi.org/10.1016/S0735-1097(84)80329-0

11. Therrien J, Marx GR, Gatzoulis MA. Late problems in tetralogy of Fallot-recognition, management, and prevention. Cardiol Clin 2002; 20:395-404.

http://dx.doi.org/10.1016/S0733-8651(02)00010-3

12. Dordjevic D. Rehabilitacija bolesnika sa bolestima srčanih zalistaka. Balneoclimatologia 2009; 33:251-60.

13. Cava JR, Danduran MJ, Fedderly RT et al. Exercise recommendations and risk factors for sudden cardiac death. Pediatr Clin North Am 2004; 51:1401-20.

http://dx.doi.org/10.1016/j.pcl.2004.04.004

14. Duppen N, Kapusta L, de Rijke ZB et al. The effect of exercise training on cardiac remodelling in children and young adults with corrected tetralogy of Fallot or Fontan circulation: A randomized controlled trial. Inter J Cardiol 2015; 179:97-104.

http://dx.doi.org/10.1016/j.ijcard.2014.10.031

15. Veshima K., Kamata J., Kobayashi N. et al. Effects of exercise training after open heart surgery on quality of life and exercise tolerance in patients with mitral regurgitation or aortic regurgitation. Jpn Heart J 2004; 45: 789-97. http://dx.doi.org/10.1536/jhj.45.789

16. Swift, Lavie CJ, Johannsen NM, et al. Physical activity,cardiorespiratory fitness and exercise training in primary and secondary coronary prevention. Circ.J.2013; 77:281-292.

17. Khairy P, Ouyang DW, Fernandes SM, et al. Pregnancy outcomes in women with congenital heart disease. Circulation 2006; 113:517-24. http://dx.doi.org/10.1161/CIRCULATIONAHA.1 05.589655

18. Balci AL, Drenthen W, Mulder BJ, et al. Pregnancy in women with corrected tetralogy of Fallot: occurrence and predictors of adverse events. Am Heart J 2011; 161:307-13. http://dx.doi.org/10.1016/j.ahj.2010.10.027 


\title{
Prikaz bolesnice nakon korektivne hirurgije tetralogije Falot
}

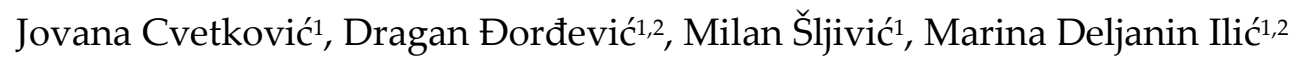 \\ ${ }^{1}$ Institut za lečenje i rehabilitaciju "Niška Banja", Niš, Srbija \\ ${ }^{2}$ Univerzitet u Nišu, Medicinski fakultet, Niš, Srbija
}

\section{SAŽETAK}

Prikazana je bolesnica stara 25 godina sa tetralogijom Fallot. Ova urođena srčana mana nije tako česta, ali je najčešća među manama sa cijanozom. Lečenje bolesnica sa tetralogijom Fallot je hirurško i može biti palijativno i korektivno. Bolesnica koju smo prikazali imala je palijativnu operaciju, definitivnu korekciju i ponovnu operaciju zbog insuficijencije pulmonalne valvule. Tokom kardiovaskularne rehabilitacije bolesnica je bila ritmički stabilna uz odličnu toleranciju fizičkog napora. Imajući u vidu da se radi o mlađoj ženskoj osobi koja je tokom proteklih godina imala dva spontana abortusa, trudnoća nije apsolutno kontraindikovana, mada su spontani abortusi i komplikacije trudnoće češći kod ovih bolesnica.

Ključne reči: tetralogia Fallot, korektivna hirurgija, pulmonalna regurgitacija, trudnoća 